\title{
RESISTANCE OF Raphanus raphanistrum TO THE HERBICIDE METSULFURON-METHYL ${ }^{1}$
}

\author{
Resistência de Raphanus raphanistrum ao Herbicida Metsulfurom Metílico \\ COSTA, L.O. ${ }^{2}$ and RIZZARDI, M.A. ${ }^{2}$
}

\begin{abstract}
The ALS-inhibiting herbicides, especially metsulfuron-methyl, are widely used for weed control, mainly wheat and barley in southern Brazil. Raphanus raphanistrum is a major weed of winter crops. However, in recent years, R. raphanistrum, after being treated with metsulfuron, has shown no symptoms of toxicity, possibly due to herbicide resistance. Aiming to evaluate the existence of $R$. raphanistrum biotypes resistant to metsulfuron, an experiment was conducted in a greenhouse, in a completely randomized design with four replications. The plots consisted of pots with six plants. The treatments consisted of the interaction of resistant $R$. raphanistrum (biotype $\mathrm{R}$ ) and susceptible $R$. raphanistrum (biotypes S) with ten doses of the herbicide $(0.0 ; 0.6 ; 1.2 ; 2.4 ; 4.8 ; 9.6 ; 19.2 ; 38.4 ; 76.8$ and $153.6 \mathrm{~g}$ i.a. ha-1). The application of the test herbicides occurred when the crop was at the stage of 3 to 4 true leaves. The variables analyzed were control and dry matter accumulation. Statistical analysis of dose-response curves was performed by non linear regression. Biotype $\mathrm{S}$ was susceptible to the herbicide even at doses below the recommended. Biotype $\mathrm{R}$ was insensitive to the herbicide obtaining values of resistance factor $(\mathrm{F})$ higher than 85 . The dose-response curve confirmed the existence of $R$. raphanistrum biotypes with high level of resistance to metsulfuron-methyl.
\end{abstract}

Keywords: acetolactate synthase, dose-response, weed, resistance factor.

RESUMO - Os herbicidas inibidores de ALS, especialmente metsulfuron metílico, são amplamente utilizados para controle de plantas daninhas, principalmente em trigo e cevada, no sul do Brasil. Raphanus raphanistrum é planta daninha comum em culturas de inverno. No entanto, nos últimos anos, plantas de $\boldsymbol{R}$. raphanistrum têm sobrevivido após o tratamento com o herbicida. Com o objetivo de avaliar a existência de biótipos de $\boldsymbol{R}$. raphanistrum resistentes ao herbicida metsulfuron, foi conduzido experimento em casa de vegetação, em delineamento inteiramente casualizado com quatro repetições. As unidades experimentais consistiram de vasos contendo seis plantas cada. Os tratamentos constaram da interação de $\boldsymbol{R}$. raphanistrum resistente (biótipo $R$ ) e suscetivel (biótipo S) com dez doses crescentes do herbicida (0,0;0,6; 1,2; 2,4; 4, 8; 9,6; 19,2; 38,4; 76,8; e 153, $6 \mathrm{~g}$ i.a. $\mathrm{ha}^{-1}$ ). A aplicação do tratamento herbicida ocorreu no estádio de três a quatro folhas verdadeiras da planta daninha. As variáveis analisadas foram controle e acúmulo de matéria seca. Empregou-se regressão, utilizando modelos não lineares de ajuste da curva de doseresposta. O biótipo $S$ foi suscetivel ao herbicida mesmo em doses abaixo da recomendada. $O$ biótipo $R$ foi insensivel ao herbicida, obtendo valores do fator de resistência (F) acima de 85. As curvas de dose-resposta confirmaram a existência de biótipos de Raphanus raphanistrum com elevado grau de resistência ao herbicida metsulfuron metílico.

Palavras-chave: acetolactato sintase, dose-resposta, planta daninha, fator de resistência.

\section{INTRODUCTION}

Resistance is the ability of the inheritable natural occurrence of some biotypes, within a given population of weeds, to survive the herbicide treatment that should, under normal use conditions, effectively control the natural population (HRAC, 2013). Now weed tolerance

Recebido para publicação em 11.9.2013 e aprovado em 23.1.2014.

Universidade de Passo Fundo, Passo Fundo-RS, Brasil, <leandro.jari@gmail.com>.

Planta Daninha, Viçosa-MG, v. 32, n. 1, p. 181-187, 2014 
to herbicides is the innate characteristic of the species to survive applications of herbicides at the recommended dose, which would be lethal to other species, without altering their growth and development. It is a pre-existing characteristic in the plant even before the first application of herbicide (Christoffoleti \& López-Ovejero, 2008).

The first report of weed resistance in Brazil has been with the species Bidens pilosa, resistant to ALS-inhibiting herbicides, in 1993 (Heap, 2013). ALS-inhibiting herbicides are widely used due to low toxicity in mammals, wide crop selectivity and high efficacy at low doses (Yu et al., 2012).

Acetolactate synthase (ALS) is the first enzyme in the common biosynthesis of branched chain amino acids: valine, leucine and isoleucine (Brown, 1990; Schloss, 1990). According to Saari et al. (1994) were identified two main mechanisms that confer resistance to ALS inhibitors: the existence of an insensitive ALS and the weed's increased ability to metabolize the herbicide. These two resistance mechanisms were found in Lolium rigidum, resistant to ALS inhibitor herbicides (Christopher et al., 1992).

Globally, ALS inhibitors are first in terms of weed resistance, totaling 129 species, including Raphanus raphanistrum in Australia and South Africa. In Brazil, there is currently documented the resistance of 31 weed species with different action mechanisms, with 14 species resistant to ALS-inhibiting herbicides (Heap, 2013).

In Brazil, the first case of resistance to ALS inhibitors, involving the genus Raphanus, was with Raphanus sativus, documented in 2001 (Heap, 2013). In the south of the country, the selection pressure caused by repetitive use of ALS inhibitors in controlling $R$. sativus selected biotypes resistant to active ingredients such as: chlorimuron ethyl, cloransulam methyl, imazethapyr, metsulfuron-methyl and nicosulfuron (Theisen, 2008).

According to Saari et al. (1994), modeling studies suggest that the frequency of mutation of initial resistance to ALS-inhibiting herbicides on weeds is about $10^{-6}$ or less, and the first resistant biotype may become apparent within five years after initiation of ALS inhibitors use. In Australia, 21\% of the population of $R$. raphanistrum is resistant to ALS-inhibiting herbicides due to the constant use of chlorsulfuron (Walsh et al., 2001). Moreover, populations of $R$. raphanistrum evolved multiple resistance to four mechanisms of herbicide action (Walsh et al., 2006).

The weed $R$. raphanistrum assumes economic importance, especially in winter crops. Being a plant that competes for nutrients and light, it also presents a threat to areas where wheat is sown, because the number of herbicides selective to this culture is limited almost exclusively to ALS inhibitors. Thus, in recent years the occurrence of biotypes of $R$. raphanistrum that after receiving treatment with methyl metsulfuron showed no signs of toxicity indicates the possibility of resistance to this herbicide. Therefore, the aim of this work was to evaluate the existence of biotypes of $R$. raphanistrum resistant to the herbicide metsulfuron-methyl.

\section{MATERIAL AND METHODS}

Were collected seeds of Raphanus raphanistrum populations with suspected resistance to ALS-inhibiting herbicides in areas where there were control failures, in northern Paraná. These seeds were sown in Passo Fundo, RS, and later, when they reached three to four true leaves, were applied $2.4 \mathrm{~g}$ i.a. ha ${ }^{-1}$ of metsulfuron-methyl $\left(\right.$ Ally $\left.^{\mathbb{R}}\right)$ for pre-selection of resistant biotypes. The plants that survived the herbicide treatment were maintained until obtaining seeds, thus providing the population with suspected resistance ( $\mathrm{R}$ biotype). To obtain the susceptible population (S biotype), seeds were collected from plants of $R$. raphanistrum in Passo Fundo, where there was no history of application of ALS inhibitors.

The experiment was conducted in a greenhouse, and experimental units consisted of pots with $17 \mathrm{~cm}$ diameter and $14 \mathrm{~cm}$ high, with a volume capacity of $2.5 \mathrm{~L}$, making the surface area of $0.0453 \mathrm{~m}^{2}$, filled with commercial substrate type Turfa Fértil ${ }^{\circledR}$. In May 2012, seeds of R and S biotypes were sown, the vessels being kept in a greenhouse with 
intermittent irrigation. After 15 days of sowing, thinning was performed, keeping six turnip plants per pot. When at the development stage of three to four true leaves, the vessels were removed from the greenhouse for application of the metsulfuron-methyl herbicide. The application was made with precision pulverizer, jet tips XR 11002, at a height of $50 \mathrm{~cm}$ above the target, with application volume of $200 \mathrm{~L} \mathrm{ha}^{-1}$. After application of the herbicide, the pots were moved to the greenhouse and remained for 24 hours without irrigation, in order not to interfere with the absorption of the herbicide.

The treatments consisted of combinations of $\mathrm{R}$ and $\mathrm{S}$ biotypes with 10 multiple doses of the herbicide metsulfuron $(0 \mathrm{D}, 0,25 \mathrm{D}$, 0,5 D, $1 \mathrm{D}, 2 \mathrm{D}, 4 \mathrm{D}, 8 \mathrm{D}, 16 \mathrm{D}, 32 \mathrm{D}$ and $64 \mathrm{D})$, where $D$ is the recommended dose for commercial control of $R$. raphanistrum $(2.4$ g i.a. ha-1). Thus, the doses that constituted the treatments were: $0.0 ; 0.6 ; 1.2 ; 2.4 ; 4.8 ; 9.6$; $19.2 ; 38.4 ; 76.8$; and 153.6 g i.a. ha ${ }^{-1}$. The treatments were arranged in a completely randomized design with four replications; the position of the pots was changed periodically in order to obtain homogeneous experimental conditions.

The control of biotypes at 14 and 35 days after application (DAA) of the herbicide was evaluated visually. For this, the basis percentage scale was used as a basis, where $0 \%$ corresponded to no herbicidal effect and $100 \%$ meant complete death of the plants in the pot. Dry matter (DM) evaluations were performed, removing three plants per pot at 14 DAA and another three at 35 DAA; later, they were dried at $65{ }^{\circ} \mathrm{C}$ for 72 hours to constant weight, when the quantification of the DM was performed.

The results of control and DM were initially subjected to analysis of variance (ANOVA) and, when $F$ values were significant $(\leq 0.05)$, regression was performed with dose-response curve fitting non-linear models.

Resistance in the dose-response curve experiment is confirmed if there is a statistical difference in response to the herbicide between the resistant biotype and the susceptible biotype, evidenced by non-linear regression models (Brain \& Cousens, 1989).
For adjustment of control data curve, the four parameter log-logistic model proposed by Streibig (1988) and Seefeldt et al. (1995) was used:

$$
y=a+\frac{b}{\left[1+\left(\frac{x}{c}\right)^{d}\right]}
$$

where: $y=$ control percentage; $x=\mathrm{D}$ dose coefficient; and $a, b, c$ and $d=$ curve coefficients, so that $a$ is the lower limit of the curve, $b$ is the difference between the maximum and minimum point of the curve, $c$ is the $\mathrm{D}$ dose coefficient that gives a $50 \%$ response of the dependent variable, and $d$ is the slope of the curve around $c$.

The DM data were converted to percentage values, starting from the principle that the plots that remained without herbicide application have 100\% DM and others have percentages of this biomass as a result of the reduction imposed by the product. For adjustment of the DM curve, the four parameters double decay exponential model (Beckie et al., 2012) was used:

$$
Y=a e^{-b x}+c e^{-d x} \quad \text { [eq. 2] }
$$

where $y=$ control percentage relative to untreated plot; $x=$ herbicide dose coefficient (g i.a. ha-1); $a=$ lower limit, $a+c=$ upper limit of the curve; and $b$ and $d$ quantify the slope of the curve.

The log-logistic model has advantages, since one of the terms in equation (c) is an estimate of the value of $\mathrm{GR}_{50}$ (Christoffoleti, 2002). According to Heap (1994), the $\mathrm{DL}_{50}$ or GR50 is the dose required to achieve 50\% control or to reduce plant DM by 50\% compared to untreated plants of resistant and susceptible biotypes. From the curves generated, one can calculate the value of $\mathrm{DL}_{50}$ or $\mathrm{GR}_{50}$ in g i.a. ha- ${ }^{-1}$.

Having the values of $\mathrm{DL}_{50}$ or $\mathrm{GR}_{50}$, the Resistance Factor (F) was obtained, which corresponded to the ratio between $\mathrm{GR}_{50}$ or $\mathrm{DL}_{50}$ of the resistant biotype compared to $\mathrm{DL}_{50}$ or $\mathrm{GR}_{50}$ of the susceptible biotype. The $\mathrm{F}$ factor $(F=R / S)$ expresses the number of times that the dose necessary to control $50 \%$ of the resistant biotype is higher than the dose that 
controls, $50 \%$ of the susceptible biotype (Hall, et al. 1998).

\section{RESULTS AND DISCUSSION}

The analysis of variance was significant for all variables analyzed, with significant interaction of factors biotypes and doses for dry matter (DM) and control at 14 and 35 days after application (DAA). The effect of the metsulfuron herbicide varied according to the biotype assessed (Figures 1 and 2). At 14 DAA, the $\mathrm{S}$ biotype was sensitive to low doses, with control of $27 \%$ at the lowest dose, reaching $93 \%$ of control at the highest dose (153.6 g i.a. ha-1). Now the $\mathrm{R}$ biotype has proved insensitive to low doses of the herbicide, reaching 3\% control at the dose of $4.8 \mathrm{~g}$ i.a. ha ${ }^{-1}$ and $53 \%$ control at the highest dose.

At 35 DAA, the $\mathrm{S}$ biotype, at the lowest dose of $0.6 \mathrm{~g}$ i.a. $\mathrm{ha}^{-1}$ controlled $80 \%$, and at the commercial dose of $2.4 \mathrm{~g}$ i.a. ha ${ }^{-1}$, controlled $99 \%$ of the population, keeping track of $100 \%$ from that dose. Now the R biotype has proved insensitive to the herbicide ultil the dose of $4.8 \mathrm{~g}$ i.a. ha ${ }^{-1}$, with $6 \%$ control at the dose of $9.6 \mathrm{~g}$ i.a. $\mathrm{h}^{-1}$ and $80 \%$ at the highest dose. Similar results were observed by Christoffoleti (2002) when testing Bidens pilosa biotypes, resistant and susceptible to ALS inhibitors, where a thousand times the recommended dose of metsulfuron did not control the resistant biotype, whereas at the recommended dose control was $100 \%$ in the susceptible population.

Based on the data generated from the curves at $14 \mathrm{DAA}$, the values for the $\mathrm{DL}_{50}$ were 1.02 and 135.11 g i.a. ha ${ }^{-1}$ for biotypes $\mathrm{S}$ and $\mathrm{R}$, respectively. Thus, the value of the resistance factor $(\mathrm{F})$ was 132 (Table 1). This means that the $\mathrm{R}$ biotype was 132 times more resistant than the S biotype.

At $35 \mathrm{DAA}$, the $\mathrm{R}$ and $\mathrm{S}$ biotypes reached $\mathrm{DL}_{50}$ of 97.34 and $0.36 \mathrm{~g}$ i.a. ha ${ }^{1}$, respectively, characterizing the $\mathrm{F}$ value of 267.4 (Table 1 ). By comparing the control periods, it is observed that the $\mathrm{R}$ biotype increased the value of $F$ at 35 DAA in respect to 14 DAA. This fact was probably due to the systemic action of metsulfuron and mainly because sulphonylureas possess a characteristic of slow control of susceptible weeds (Brown, 1990).

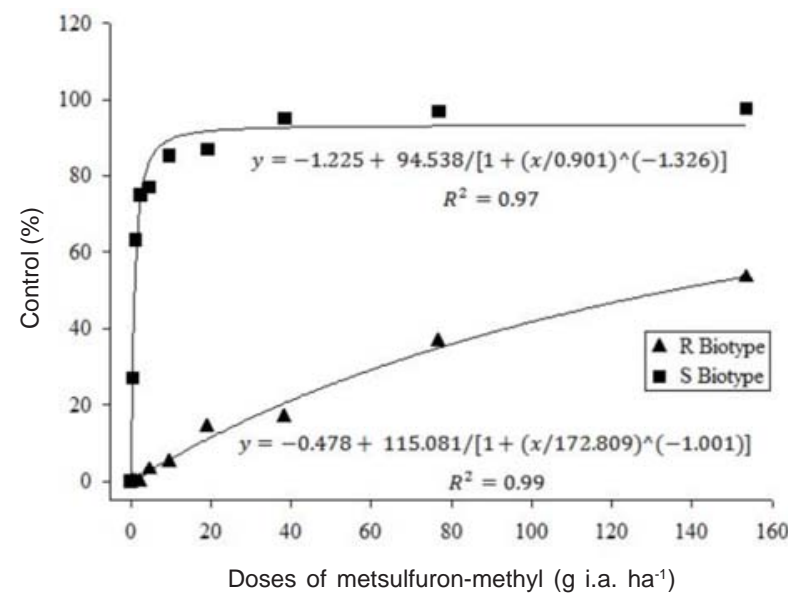

Figure 1 - Control (\%) and equation parameters at 14 days after application, for the resistant (R) and susceptible (S) biotypes. Passo Fundo, RS, 2012.

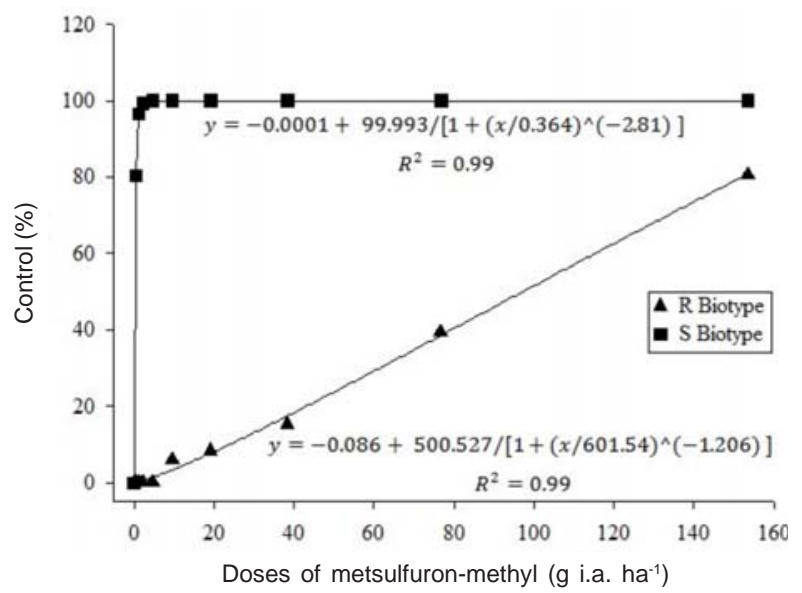

Figure 2 - Control (\%) and equation parameters at 35 days after application, for the resistant (R) and susceptible (S) biotypes. Passo Fundo, RS, 2012.

Table 1 - Dose required to control 50\% of the plants compared to untreated plants $\left(\mathrm{DL}_{50}\right)$ and resistance factor $(\mathrm{F})$ of the resistant (R) and susceptible (S) biotypes of $R$. raphanistrum at 14 and 35 days after application (DAA) of metsulfuron-methyl. Passo Fundo, RS, 2012

\begin{tabular}{|c|c|c|c|}
\hline $\begin{array}{c}\text { Control } \\
\text { evaluation } \\
\text { (DAA) }\end{array}$ & Biotypes & $\begin{array}{c}\mathrm{DL}_{50} \\
(\mathrm{~g} \text { i.a. ha }\end{array}$ & F Factor \\
\hline 14 & $\mathrm{R}$ & 135.11 & 132 \\
\hline 14 & $\mathrm{~S}$ & 1.02 & - \\
\hline 35 & $\mathrm{R}$ & 97.34 & 267 \\
\hline 35 & $\mathrm{~S}$ & 0.36 & - \\
\hline
\end{tabular}


Thus, by the control results in the two seasons, it was evident the high degree of resistance of the $\mathrm{R}$ biotype to the herbicide metsulfuron at the commercial dose of 2.4 g i.a. ha ${ }^{-1}$ and, above this, controls the population of the $\mathrm{S}$ biotype (Figure 3 ).

$\mathrm{DM}$ results differ between $\mathrm{R}$ and $\mathrm{S}$ biotypes, both at 14 and 35 DAA (Figures 4 and 5). At 14 DAA, at all doses of metsulfuron, DM was reduced in the $\mathrm{R}$ and $\mathrm{S}$ biotypes compared with the control (plot with no herbicide). At the lowest dose (0.6 g i.a. ha $\left.{ }^{-1}\right)$ DM was reduced to 5 and $33 \%$ in the $\mathrm{R}$ and $\mathrm{S}$ biotypes, respectively, compared to the control. When applied 153.6 g i.a. ha-1, DM was reduced in $78 \%$ and $96 \%$ in the $\mathrm{R}$ and $\mathrm{S}$ biotypes, respectively.

At 35 DAA, DM was also reduced for both biotypes. However, the $\mathrm{S}$ biotype at the dose of 1.2 g i.a. ha ${ }^{-1}$ reduced $88 \%$ of DM compared to untreated plants, while for the $\mathrm{R}$ biotype the reduction was $7 \%$. At the highest dose (153.6 g i.a. ha ${ }^{-1}$ ) the $\mathrm{R}$ biotype reduced $93 \%$ of DM compared to control. Now for the S biotype, from the dose of 2.4 g i.a. ha-1, DM was reduced by $100 \%$, with complete death of the plants. In Australia, a biotype of $R$. raphanistrum suspect of resistance, when subjected to a dose of $90 \mathrm{~g}$ i.a. ha ${ }^{-1}$ chlorsulfuron, had a rate of $89-100 \%$ survival. Now the susceptible biotype was controlled in 70 to $100 \%$, with doses of 15 and $60 \mathrm{~g}$ i.a. ha $\mathrm{h}^{-1}$, respectively (Hashem et al., 2001).

The results of $\mathrm{GR}_{50}$ and $F$ value for the $R$ and $\mathrm{S}$ biotypes at 14 and 35 DAA are described in Table 2. At $14 \mathrm{DAA}$, the values of $\mathrm{GR}_{50}$ and the factor $\mathrm{F}$ show that the $\mathrm{S}$ biotype reduced $50 \%$ of DM with $1.22 \mathrm{~g}$ i.a. ha ${ }^{-1}$, while the $\mathrm{R}$ biotype required 29.9 times this dose to achieve the same reduction. At 35 DAA, the differences between the biotypes were higher: the $\mathrm{R}$ biotype was found to be 85 times more resistant than the $\mathrm{S}$ biotype to the herbicide dose that controls $50 \%$ of the population. Similar to the control evaluation (Table 1), the value of $\mathrm{F}$ was higher to 35 DAA compared to 14 DAA.

High resistance rates $(\mathrm{F})$ observed for this herbicide may also be related to the high susceptibility of the susceptible population

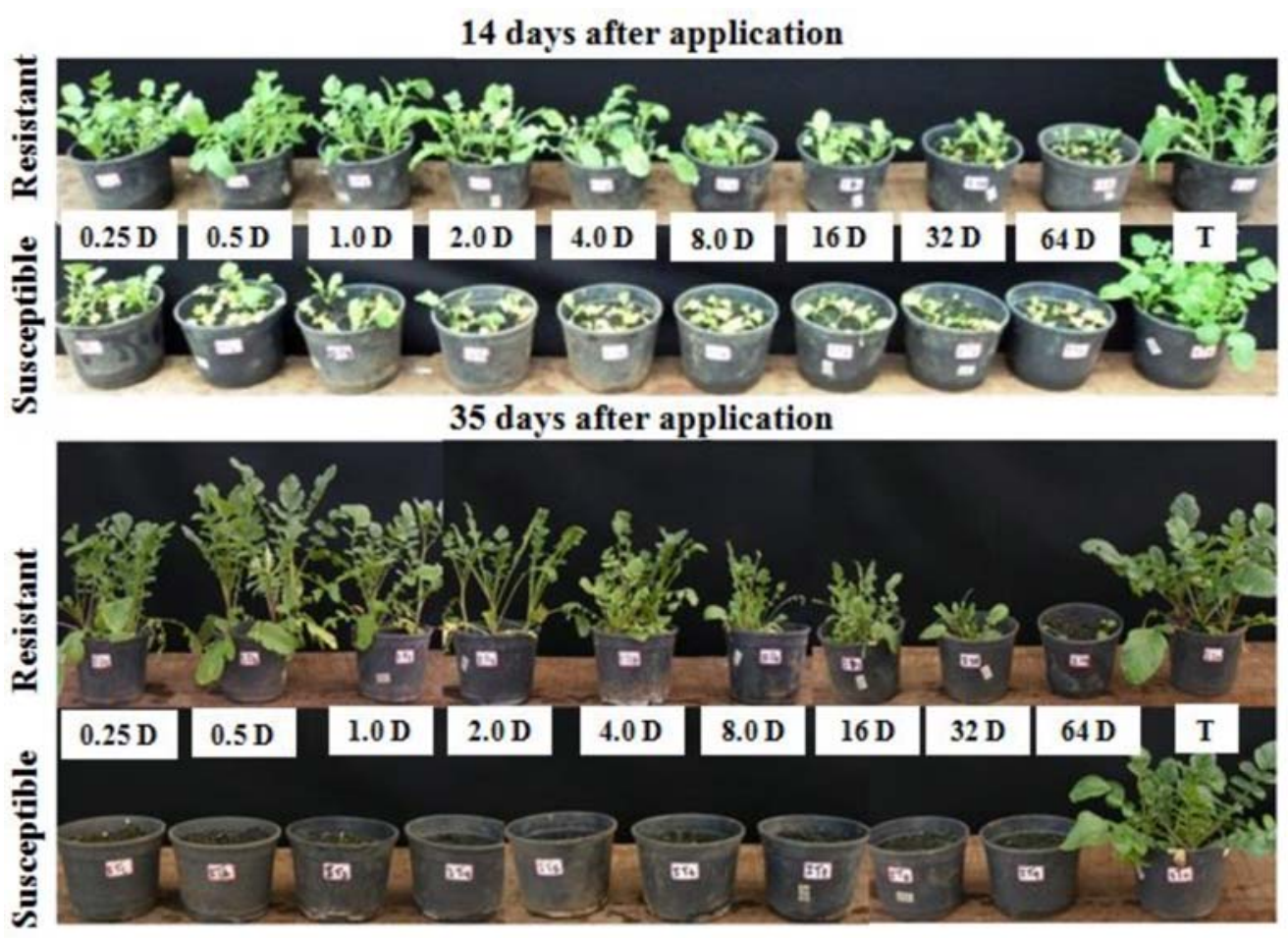

Figure 3 - Control of the biotype $R$. raphanistrum resistant and susceptible at 14 and 35 days after application of increasing doses of metsulfuron-methyl. The dose administered in each treatment (vessel) is represented by the number of times multiplying D, where D is the commercial dose (2.4 g i.a. ha-1). Passo Fundo, RS, 2012. 


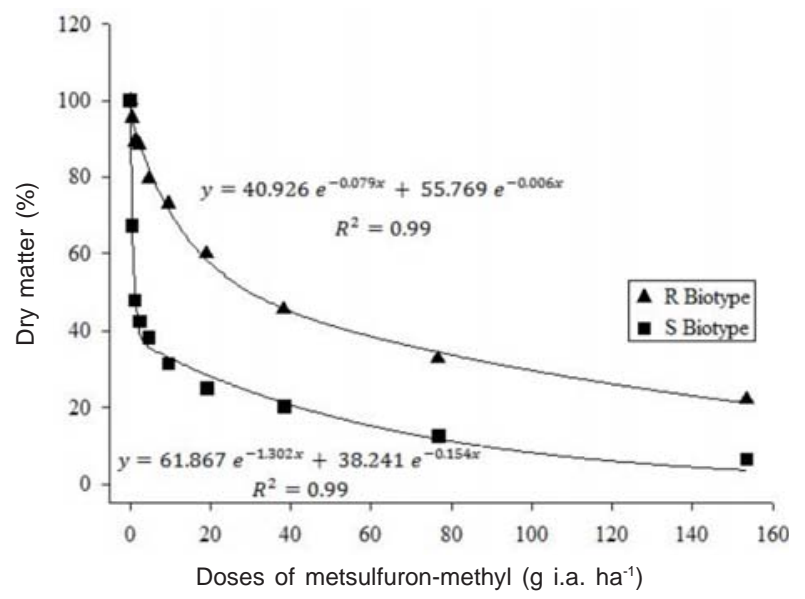

Figure 4 - Dry matter (\%) in relation to the plot without herbicide and equation parameters for the resistant (R) and susceptible (S) biotypes, 14 days after application of metsulfuron-methyl. Passo Fundo, RS, 2012.

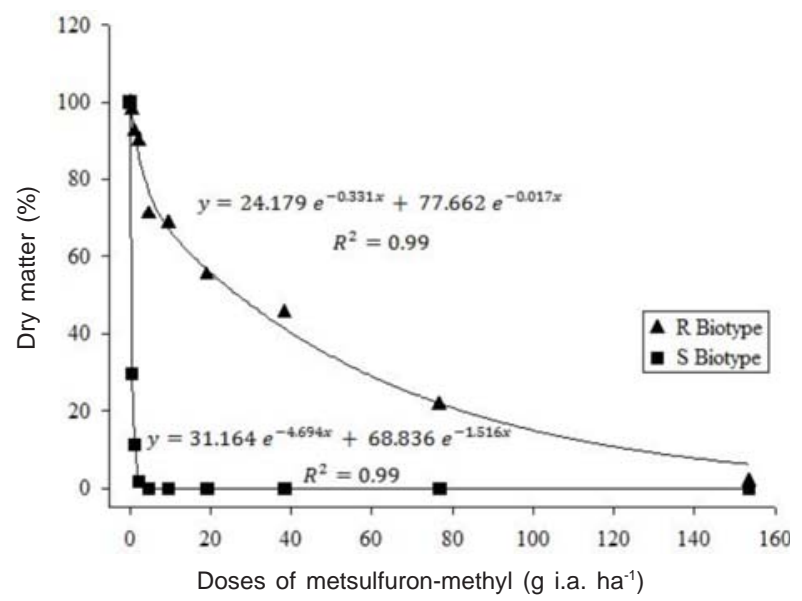

Figure 5 - Dry matter (\%) in relation to the plot without herbicide and equation parameters for the resistant (R) and susceptible (S) biotypes, 35 days after application of metsulfuron-methyl. Passo Fundo, RS, 2012.

Table 2 - Dose required to reduce dry matter of plants to 50\% compared to untreated plants $\left(\mathrm{GR}_{50}\right)$ and resistance factor (F) of the resistant (R) and susceptible (S) biotypes of $R$. raphanistrum at 14 and 35 days after application (DAA) of metsulfuron-methyl. FAMV-UPF, Passo Fundo, RS, 2012

\begin{tabular}{|c|c|c|c|}
\hline $\begin{array}{c}\text { Control } \\
\text { evaluation } \\
\text { (DAA) }\end{array}$ & Biotypes & $\begin{array}{c}\mathrm{DL}_{50} \\
\left(\mathrm{~g} \mathrm{i.a.} \mathrm{ha}^{-1}\right)\end{array}$ & F Factor \\
\hline 14 & $\mathrm{R}$ & 29.950 & 24 \\
\hline 14 & $\mathrm{~S}$ & 1.225 & - \\
\hline 35 & $\mathrm{R}$ & 26.60 & 85 \\
\hline 35 & $\mathrm{~S}$ & 0.313 & - \\
\hline
\end{tabular}

(López-Ovejero et al., 2005). This fact is confirmed by the high susceptibility of the S biotype, which at the lowest dose of 0.6 g i.a. ha ${ }^{-1}$ obtained control of over $80 \%$ in evaluations at 35 DAA.

The variation in resistance rates between methods of assessment, control regarding DM, was due to the fact that the control effect is evaluated by the degree of phytotoxicity and the percentage of necrotic tissue and killed by herbicide action. Thus, minor variations, such as reduced size, reduced leaf area, among others, are not noticeable. Thus, DM becomes a more real evaluation of the efficacy of herbicides, especially in dose-response curve experiments, where it is necessary to measure small changes in plant development, exceptionally when the weed is characterized with low resistance level.

Studies with $R$. raphanistrum demonstrated that resistance was due to an altered site of ALS enzyme action (Walsh et al., 2006). High resistance rates in control and DM evaluations, with $\mathrm{F}$ values of 267 and 85, respectively, at $35 \mathrm{DAA}$, may be related to a change in the molecular basis of resistance to ALS inhibitors. In a recent work with the homozygous population of $R$. raphanistrum resistant to ALS inhibitors, Han et al. (2012) observed a change on a molecular basis in the resistance of this population, which was identified as a mutation of alanine for tyrosine at amino acid position 122 of the ALS gene. This mutation conferred high levels of resistance to the following chemical groups of ALS inhibitors: sulfonylureas $(F>1024)$, triazolopirimidines $(>516)$ and imidazolinones $(\mathrm{F}=16)$.

According to heap (2013), the criterion for documenting resistance is when the resistance factor $(\mathrm{F})$ is greater than 10 , based on $\mathrm{GR}_{50}$ or $\mathrm{DL}_{50}$. Through the results of resistance rates obtained by adjusting the dose-response curves, it is correct to say that the $\mathrm{R}$ biotype has a high degree of resistance to the herbicide metsulfuron-methyl because the resistance factor in all assessments was higher than $10(\mathrm{~F}>10)$ and $\mathrm{S}$ biotype showed to be susceptible to this herbicide.

The confirmation of the resistance of the Raphanus raphanistrum biotype to the ALS 
inhibitor herbicide metsulfuron-methyl, which predominates in the winter and during almost the entire summer in production crops in southern Brazil, sees the need to establish management strategies for prevention and control of resistance to ALS inhibitors, being high risk herbicides for the selection of resistant biotypes.

\section{LITERATURE CITED}

BECKIE, H. J. et al. Acetolactate synthase (ALS) inhibitorresistant wild buckwheat (Polygonum convolvulus) in alberta. Weed Technol., v. 26, n. 1, p. 156-160, 2012.

BRAIN, P.; COUSENS, R. An equation to describe dose responses where there is istimulation of growth at low doses. Weed Res., v. 29, n. 2, p. 93-96, 1989.

BROWN, H. M. Mode of action, crop selectivity, and soil relations of the sulfonylurea herbicides. Pest. Sci., v. 29, n. 3, p. 263-281, 1990.

CHRISTOFFOLETI, P. J. Curvas de dose-resposta de biótipos resistente e suscetível de Bidens pilosa L. aos herbicidas inibidores da ALS. Sci. Agric., v. 59, n. 3, p. 513-519, 2002.

CHRISTOFFOLETI, P. J.; LÓPEZ-OVEJERO, R. F. Resistência das plantas daninhas a herbicidas: definições, bases e situação no Brasil e no mundo. In:

CHRISTOFFOLETI, P. J. (Coord.). Aspectos de resistência de plantas daninhas a herbicidas. 3.ed. Piracicaba: Associação Brasileira de Ação a resistência de Plantas aos Herbicidas (HRAC-BR), 2008. p. 934.

CHRISTOPHER, J. T et al. Resistance to acetolactate synthase-inhibiting herbicides in annual ryegrass (Lolium rigidum) involves at least two mechanisms. Plant Physiol., v. 100, n. 4, p. 1909-1913, 1992.

HALL, L. M. et al. Resistance to acetolactate synthase inhibitors and quinclorac in a biotype of false clover (Gallium spurium). Weed Sci., v. 46, n. 4, p. 390-396, 1998.

HAN, H. et al. A novel amino acid substitution Ala-122-Tyr in ALS confers high-level and broad resistance across ALSinhibiting herbicides. Pest Manag. Sci., v. 68, n. 8, p. 1164-1170, 2012.

HASHEM, A. et al. Resistance of wild radish (Raphanus raphanistrum) to acetolactate synthase-inhibiting herbicides in the western Australia wheat belt weed. Weed Technol., v. 15, n. 1, p. 68-74, 2001.
HEAP, I. International Survey of Herbicide resistant Weeds. Disponível em: http: <//www.weedscience.org/ In.asp>. Acesso em: 5 jan. 2013.

HEAP, I. M. Identification and documentation of herbicide resistance. Phytoprotection, v. 75, n. 4, p. 85-90, 1994.

HRAC. Herbicide Resistance Action Committee. Disponível em: <http://www.hracglobal.com/>. Acesso em: 15 jan. 2013.

LÓPEZ-OVEJERO, R. F. et al. Resistência de populações de capim-colchão (Digitaria ciliaris) aos herbicidas inibidores da acetil Co-A carboxilase. Planta Daninha, v. 23, n. 3, p. 543-549, 2005.

SAARI, L. L. et al. Resistance to acetolactate synthase inhibiting herbicides. In: POWLES, S. B.; HOLTUM, A. M. Herbicide resistance in plants: biology and biochemistry. Boca Raton: Lewis Publishers, 1994. p. 83-139.

SCHLOSS, J. V. Acetolactate synthase, mechanism of action and its herbicide binding site. Pestic. Sci., v. 29, n. 3, p. 283-292, 1990.

SEEFELDT, S. S. et al. Log-logistic analysis of herbicide dose-response relationships. Weed Technol., v. 9, n. 2, p. 218-227, 1995.

STREIBIG, J. C. Herbicide bioassay. Weed Res., v. 28, n. 6, p. 479-484, 1988.

THEISEN, G. Aspectos botânicos e relato a resistência de nabo silvestre aos herbicidas inibidores de ALS. Pelotas: Embrapa Clima Temperado, 2008. 26 p. (Documento, 239).

WALSH, M. J. et al. High frequency of chlorsulfuronresistant wild radish (Raphanus raphanistrum) populations across the western Australian wheat belt. Weed Technol., v. 15, n. 2, p. 199-203, 2001.

WALSH, M. J. et al. Frequency, distribution and mechanisms of herbicide resistance in Western Australian wild radish (Raphanus raphanistrum L.) populations: a review. In: AUSTRALIAN WEEDS CONFERENCE, 15., 2006, Adelaide. Proceedings... Adelaide: 2006. p. 484-487.

YU, Q. et al. Resistance evaluation for herbicide resistanceendowing acetolactate synthase (ALS) gene mutations using Raphanus raphanistrum populations homozygous for specific ALS mutations. Weed Res., v. 52, n. 2, p. 178-186, 2012. 